\title{
PENGARUH PRA-PERLAKUAN MADU TERHADAP FARMAKOKINETIKA ELIMINASI RIFAMPISIN PADA TIKUS WISTAR JANTAN
}

\author{
Dimas Adhi Pradana ${ }^{1^{*}}$, Farida Hayati ${ }^{2}$, Dian Sukma ${ }^{3}$ \\ Prodi Farmasi Fakultas Matematika dan IImu Pengetahuan Alam \\ Universitas Islam Indonesia \\ *email : adhi_pradana85@yahoo.com
}

\begin{abstract}
ABSTRAK
Rifampisin merupakan salah satu obat yang dipergunakan sebagai terapi lini pertama dalam pengobatan tuberkulosis. Tujuan dari penelitian ini untuk mengetahui pengaruh pra-perlakuan pemberian madu terhadap profil farmakokinetika fase eliminasi rifampisin pada tikus Wistar Jantan. Dalam penelitian ini hewan uji dibagi menjadi 2 kelompok, yaitu kelompok kontrol dan perlakuan. Setiap kelompok terdiri dari 5 ekor tikus. Kelompok kontrol diberikan rifampisin dosis tunggal $50 \mathrm{mg} / \mathrm{kg}$ tikus sedangkan kelompok perlakuan diberikan madu $7,65 \mathrm{ml} / \mathrm{kg}$ secara oral sekali sehari selama 7 hari dan pada hari ke-8 diberikan rifampisin dosis $50 \mathrm{mg} / \mathrm{kg}$ BB tikus secara per oral. Sebanyak $0,2 \mathrm{ml}$ sampel darah diambil dari vena lateralis ekor pada 0.25 ; $0.5,1.0,1.5,2.0,3.0 ; 4.0 ; 6.0 ; 8,0 ; 10.0$; 12.0, dan 24.0 jam. Penetapan kadar rifampisin dalam plasma dilakukan dengan metode HPLC pada panjang gelombang $244.6 \mathrm{~nm}$. Parameter farmakokinetika fase eliminasi yang ditetapkan adalah $k, t \frac{1}{2}$, dan $\mathrm{Cl}_{\mathrm{T}}$. Hasil penelitian menunjukkan bahwa pemberian pra perlakuan madu tidak mempengaruhi farmakokinetika fase eliminasi dari rifampisin.
\end{abstract}

Keywords : HPLC, madu, farmakokinetika, ricampicin

\section{ABSTRACT}

Rifampicin is one of the first-line drug for the therapy of Tuberculosis (TB), which is still commonly used. The aim of the study is to determine the effect of pretreatment with honey on the pharmacokinetic profile of orally administered rifampicin on male Wistar rats. In this study, animals were divided into two groups, each group consists of 5 rats. The group I were given a single dose of rifampicin $50 \mathrm{mg} / \mathrm{kg}$ orally as a control, while the group II were given a single doses of honey $7.65 \mathrm{~mL} / \mathrm{kg}$ orally once daily for seven days. On the day $8^{\text {th }}$ the rats were given concurrently with rifampicin dose of $50 \mathrm{mg} / \mathrm{kg}$ orally. $0.2 \mathrm{~mL}$ of blood was taken through the rats lateral tail vein at $0.25 ; 0.5,1.0,1.5,2.0$, $3.0 ; 4.0 ; 6.0 ; 8,0 ; 10.0 ; 12.0$, and 24.0 hours. Determination of rifampicin levels in plasma were analyzed by HPLC at a wavelength of $244.6 \mathrm{~nm}$. Parameters obtained from the two groups were statistically analyzed through the normality test followed by unpaired t test with a level of $95 \%$. The results showed that the pretreatment of honey does not have a significant effect on the elimination phase of rifampicin based on $\mathrm{t} 1 / 2$

Keywords: honey, HPLC, pharmacokinetics, rifampicin

\section{PENDAHULUAN}

Interaksi obat pada fase eliminasi merupakan hal yang penting untuk diketahui karena terkait dengan efektivitas proses metabolism dan atau ekskresi obat. Profil farmakokinetika eliminasi suatu obat dapat berubah oleh adanya obat lain, obat herbal bahkan makanan dan minuman. Hal tersebut dapat disebabkan karena terjadinya interaksi farmakokinetika yang dapat merubah profil absorbsi, distribusi, metabolisme dan eksresi dari suatu obat (Baxter, 2008). Rifampisin merupakan obat lini pertama yang berguna dalam pengobatan TB (Debra et al, 1999). Rifampisin merupakan obat yang bersifat 
autoinducer, hal ini dikarenakan rifampisin merupakan substrat CYP 3A4 sekaligus sebagai induktor kuat CYP 3A4 (Goodman \& Gilman's, 2000).

Madu merupakan minuman yang memiliki nilai gizi tinggi dan berkhasiat untuk mengobati berbagai penyakit. Setiap orang dapat mengonsumsi madu, baik anak-anak, dewasa, maupun orang tua (Suranto, 2004). Madu memiliki pengaruh besar sebagai nutraceutical. Madu juga memiliki aktivitas sebagai antimikroba, antivirus, dan antiparasit, antimutagenik, antitumor, berperan sebagai antioksidan, dan juga memiliki efek antiinflamasi (Bogdanov et al, 2008). Selain itu, madu juga diyakini dapat meningkatan daya tahan tubuh pasien tuberkulosis (Suranto, 2007). Kandungan flavonoid pinocembrin, pinobanksin, chrysin, galangin, quercetin and luteolin pada madu diketahui dapat menginduksi aktivitas enzim sitokrom P450, terutama enzim CYP3A4, sehingga dimungkinkan dapat mempengaruhi metabolisme rifampisin (Tushar et al, 2006)

Penggunaan Rifampisin bersama madu memungkinkan adanya interaksi sehingga dapat mempengaruhi profil farmakokinetika obat antituberkulosis terutama pada fase eliminasi. Penelitian sebelumnya menunjukkan bahwa madu dapat mempengaruhi profil farmakokinetika dan efektifitas beberapa obat. Sebuah penelitian mengenai pengaruh praperlakuan madu terhadap profil farmakokinetika sulfametazin pada tikus jantan menunjukkan bahwa madu dapat meningkatkan nilai $\mathrm{T}_{\text {maks }}$, $\mathrm{Vd}, \mathrm{t}_{1 / 2}, \mathrm{Cl}_{\mathrm{T}}$, dan menurunkan harga $\mathrm{ka}$, $\mathrm{C}_{\text {maks, }} \mathrm{AUC}$, dan k sulfametazin (Maulidah, 2005). Penelitian lain mengenai pemberian madu dosis $46 \mathrm{ml} / \mathrm{kg} \mathrm{BB} ; 8,19 \mathrm{ml} / \mathrm{kg} \mathrm{BB}$; dan
$10,92 \mathrm{ml} / \mathrm{kg}$ BB yang diberikan bersamaan dengan parasetamol pada mencit betina galur Swiss dapat menyebabkan kenaikan efek analgetika parasetamol (Trisnawati, 2005). Pemberian madu juga dapat mempengaruhi profil farmakokinetika teofilin berupa penurunan nilai $\mathrm{Ka}$ dan $\mathrm{Cp}_{\text {maks, }}$ serta peningkatan nilai $\mathrm{T}_{\text {maks, }} \mathrm{Vd}$, dan $\mathrm{Cl}_{\mathrm{T}}$ secara bermakna (Paramitasari, 2012).

Beberapa uraian yang telah dikemukakan diatas melatarbelakangi penelitian tentang interaksi antara madu dengan rifampisin yang dapat mempengaruhi profil farmakokinetika rifampisin khususnya fase eliminasi.

\section{METODE PENELITIAN}

Alat - alat yang digunakan alat-alat gelas seperti kaca arloji, gelas beker, gelas ukur, labu ukur, erlenmeyer, dan batang pengaduk, timbangan elektrik, stopwatch, spatula, pipet volume, pipet ukur, mikropipet, spuit injeksi 1-5 mL, flacon, jarum oral, ependorf, sentrifuge Hanil MF 80, vortex type 16700 mixer dan seperangkat alat spekrofotometer Shimadzu UV-Vis 1800, HPLC Water e2695, detektor UV 2487 pada $244,6 \mathrm{~nm}$, kolom Sunfire $C_{18}(5 \mu \mathrm{m}) 4,6 \times 150$ $\mathrm{mm}$, injektor SM7, perangkat lunak Empower (versi 2.0, Waters Corporation).

Bahan-bahan yang digunakan dalam penelitian ini meliputi rifampisin serbuk murni yang diperoleh dari PT Sanbe Farma, madu kelengkeng "Seribu Bunga", kalium dihidrogen fosfat (kualitas analisis, Merck), asetonitril (kualitas ultra gradient solvent untuk HPLC, J.T. Baker), metanol (kualitas solvent untuk HPLC, J.T.Baker), asam askorbat (kualitas analisis, Merck), heparin 
sodium (Inviclot ${ }^{\circledR}$ ), asam ortofosfat (Merck) dan akuabidestilata.

Hewan uji dalam penelitian ini adalah tikus putih (Rattus norvegicus) jantan galur Wistar yang diperoleh dari LPPT (Laboratorium Penelitian dan Pengujian Terpadu) UGM, berat badan tikus $180-250 \mathrm{~g}$ dan berumur 2-3 bulan.

Pada metode penetapan kadar rifampisin dalam darah dilakukan proses sentrifuge dilakukan selama 5 menit dengan kecepatan 10.000 rpm. Analisis kadar rifampisin dalam darah dilakukan dengan menggunakan HPLC metode fase terbalik (fase gerak bersifat polar dan fase diam bersifat non polar), menggunakan kolom ODS C18. Sebanyak $200 \mu$ l plasma dipipet ke flacon kemudian tambahkan $400 \mu \mathrm{l}$ asetonitril, vortex selama 1 menit dan disentrifuse selama 30 menit dengan kecepatan 4.000 rpm. Darah diambil beningannya dan dimasukkan kedalam vial injektor lalu diinjeksikan ke HPLC sebanyak $20 \mu \mathrm{l}$ secara auto injeksi. Fase gerak yang digunakan adalah 0,05 $\mathrm{M}$ buffer fosfat $(\mathrm{pH}$ $2,6)$ : asetonitril $(55: 45 \mathrm{v} / \mathrm{v})$ dengan laju alir $1,2 \mathrm{ml} / \mathrm{menit}$ pada panjang gelombang 244,6 $\mathrm{nm}$ (Kumar et al, 2004).

\section{Uji pendahuluan}

a. Optimasi metode analisis

1. Penetapan panjang gelombang maksimum

Rifampisin dilarutkan dalam fase gerak 0,05 M buffer fosfat : asetonitril (55:45 v/v) dengan kadar $20 \mu \mathrm{g} / \mathrm{ml}$ kemudian di baca pada spektrofotometer UV-Vis dengan panjang gelombang pada range 200-400 $\mathrm{nm}$.

2. Penetapan waktu retensi dan selektivitas rifampisin
Rifampisin murni dilarutkan dalam metanol hingga konsentrasi $5 \mu \mathrm{g} / \mathrm{ml}$. Hasil larutan dimasukkan dalam vial injektor, diambil secara autoinjeksi dalam jumlah $20 \mu \mathrm{L}$ ke dalam HPLC dengan menggunakan kolom C18, fase gerak $0,05 \mathrm{M}$ buffer fosfat : asetonitril (55:45 v/v) dengan laju alir 1,2 $\mathrm{ml} /$ menit dan panjang gelombang maksimum yang sudah didapatkan sebelumnya, kemudian ditetapkan waktu retensi dan selektivitas rifampisin.

3. Penetapan persamaan kurva baku rifampisin dalam darah

Dalam pembuatan kurva baku dilakukan pembuatan larutan stok rifampisin dengan cara melarutkan $10 \mathrm{mg}$ rifampisin dalam 10 $\mathrm{ml}$ metanol dan ditambahkan dengan 0,5 $\mathrm{mg} / \mathrm{ml}$ asam askorbat. Diambil sejumlah rifampisin dari larutan stok kemudian ditambahkan 0,2 $\mathrm{ml}$ plasma setelah dikurangi volume larutan stock yang ditambahkan untuk membuat konsentrasi 0,$5 ; 1 ; 2 ; 5$, dan $10 \mu \mathrm{g} / \mathrm{ml}$ dalam $200 \mu \mathrm{l}$ darah. Pengerjaan standar rifampisin dilakukan dalam range konsentrasi 0,5-10 $(0,5 ; 1 ; 2 ; 5$, dan 10$) \mu \mathrm{g} / \mathrm{ml}$ dan tambahkan $400 \mu \mathrm{L}$ asetonitril. Vortex selama 1 menit dan disentrifuse selama 30 menit dengan kecepatan 4.000 rpm. Diambil beningannya dan diinjeksikan ke HPLC sebanyak $20 \mu \mathrm{l}$ secara auto injeksi. Regresi linear ditentukan dengan analisis tinggi puncak terhadap kurva konsentrasi. Linearitas ditentukan dengan koefisien korelasi (r) (Kumar et al, 2004).

4. Penetapan stabilitas rifampisin dalam pelarut

Diambil $200 \mu \mathrm{L}$ darah dari hewan uji yang telah diberikan rifampisin secara oral dosis $50 \mathrm{mg} / \mathrm{Kg}$ BB dan ditambahkan $400 \mu \mathrm{L}$ asetonitril, kemudian divortex selama 1 
menit dan disentrifuse selama 30 menit dengan kecepatan $4.000 \mathrm{rpm}$, diambil beningannya. Larutan bening di simpan pada suhu $2-8^{0} \mathrm{C}$ selama 24 . Kadar rifampisin ditetapkan dengan HPLC pada jam ke-0 dan 24. Hasil yang diperoleh dinyatakan sebagai persen degradasi rifampisin selama penyimpanan dalam pelarut metanol dengan penambahan asam askorbat (Anonim, 2009).

5. Penentuan kriteria kecermatan (accurate)

Kadar rifampisin dalam darah dibuat dengan dengan cara melarutkan sejumlah tertentu rifampisin dalam $10 \mathrm{ml}$ metanol dan ditambahkan dengan $0,5 \mathrm{mg} / \mathrm{ml}$ asam askorbat. Dibuat konsentrasi 5, 10 dan 15 $\mu \mathrm{l} / \mathrm{ml}$ dengan replikasi 3 kali. Divortex selama 1 menit dan disentrifuse selama 30 menit dengan kecepatan 4.000 rpm lalu diambil beningannya dan diinjeksikan ke HPLC sebanyak $20 \mu \mathrm{l}$ secara auto injeksi (Anonim, 2009).

6. Penentuan kriteria ketepatan (precise)

Nilai kesalahan acak mencerminkan presisi yang diperoleh dalam suatu metode. Rentang penerimaan yang diperbolehkan untuk metode HPLC adalah kurang dari 15\% (Anonim, 2009)

7. Penetapan batas deteksi dan kuantifikasi kadar rifampisin

Penetapan batas deteksi dan kuantifikasi dihitung melalui persamaan regresi linier yang sudah didapat pada penetapan kurva baku.

\section{b. Penetapan dosis}

Dosis rifampisin yang digunakan sesuai dengan dosis pada penelitian sebelumnya yaitu $50 \mathrm{mg} / \mathrm{kgBB}$ tikus (setara dengan 560 $\mathrm{mg} / 70 \mathrm{~kg}$ BB manusia) (Wahyono dkk, 2007), sedangkan dosis madu yang dipergunakan sebesar 7,65 mL/kgBB tikus (Trisnawati, 2005).

C. Penetapan waktu sampling

Waktu sampling yang digunakan pada penelitian ini berdasarkan waktu sampling penelitian sebelumnya yakni pada jam ke 0,$25 ; 0,5 ; 1 ; 1,5 ; 2 ; 3 ; 4 ; 6 ; 8 ; 10 ; 12$; dan 24 (Wahyono \& Hakim, 2005)

\section{HASIL DAN PEMBAHASAN}

Penelitian ini sudah memenuhi syarat secara etik dan mendapatkan surat kelayakan etik (ethical clearance) nomor 103/KEC-LPPT/V/2013 dari Komite Etik Penelitian Hewan Coba Laboratorium Penelitian dan Pengujian Terpadu (LPPT) Universitas Gadjah Mada

1. Penetapan panjang gelombang maksimum rifampisin

Penetapan panjang gelombang maksimum ( $\left.\lambda_{\text {maks }}\right)$ rifampisin dibaca dengan menggunakan spektrofotometer UV-Vis. Hasil yang diperoleh menunjukkan bahwa panjang gelombang maksimum rifampisin terdapat pada panjang gelombang 244,6 nm 



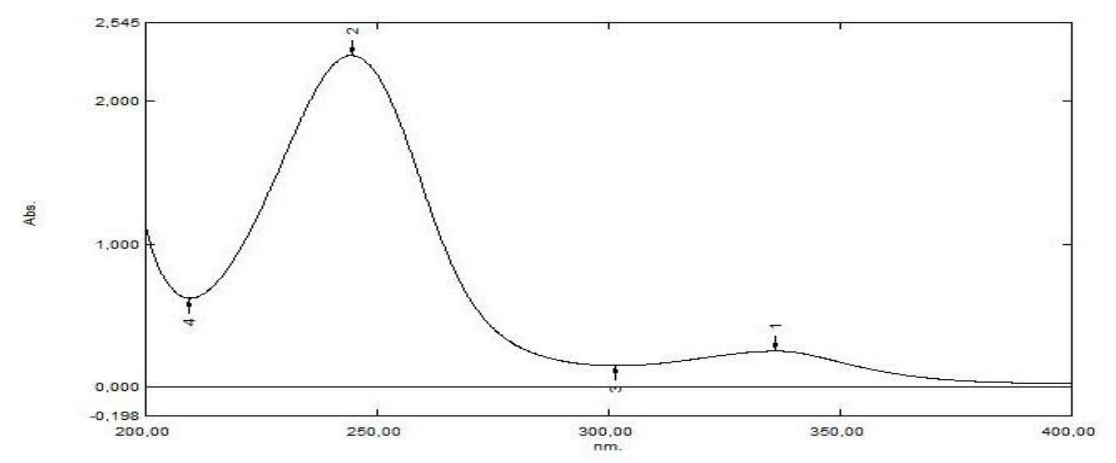

Gambar 1. Kromatogram spektrofotometri UV-Vis panjang gelombang Rifampisin

2. Penetapan waktu retensi

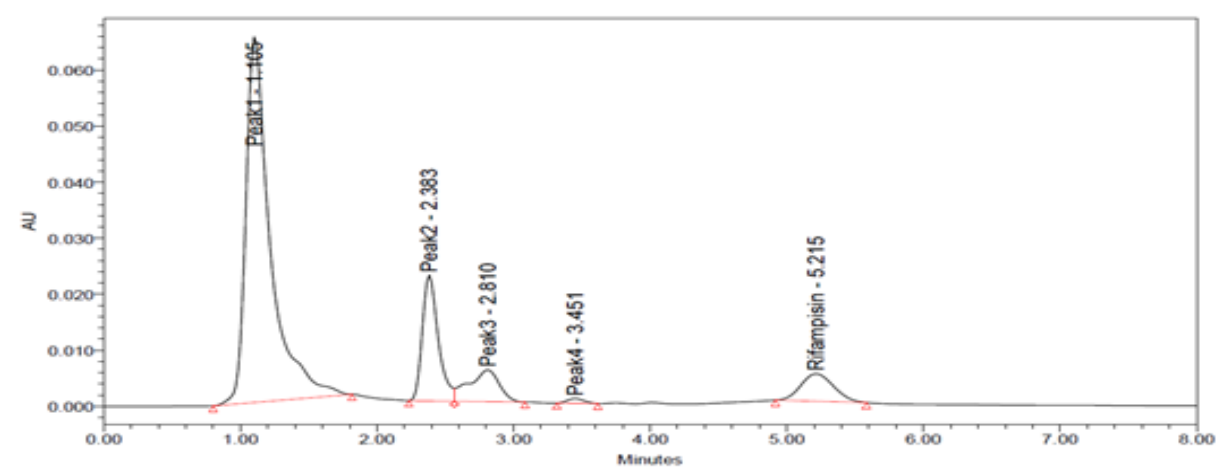

Gambar 2. Kromatogram rifampisin dalam darah (in vivo) sampel jam ke 8 pada tikus kontrol 1 dengan fase gerak $0,05 \mathrm{M}$ buffer fosfat : asetonitril $(55: 45 \mathrm{v} / \mathrm{v})$

Berdasarkan hasil penelitian, retensi 5,215 menit, sedangkan senyawa endogen darah terdekat memiliki waktu retensi 3,451.

3. Penetapan persamaan kurva baku rifampisin dalam darah
Penetapan persamaan kurva baku rifampisin dalam darah dilakukan dengan membuat beberapa seri kadar yang kemudian diukur luas area dibawah puncak kromatogramnya dengan menggunakan HPLC.

Tabel 1. Pembacaan luas area dibawah puncak kromatogram pada beberapa seri kadar rifampisin dalam darah

\begin{tabular}{ccc}
\hline No & $\begin{array}{c}\text { Seri Kadar } \\
(\mu \mathrm{g} / \mathrm{mL})\end{array}$ & Luas Area \\
\hline 1 & 0,5 & 9959 \\
2 & 1 & 19153 \\
3 & 2 & 47880 \\
4 & 5 & 91928 \\
5 & 10 & 197905 \\
\hline
\end{tabular}


Persamaan kurva baku yang diperoleh adalah $\mathrm{y}=19438,99676 \mathrm{x}+1440,71197$; $x$ adalah kadar rifampisin dalam darah dan y adalah luas area dibawah puncak kromatogram rifampisin hasil dari pengukuran dengan HPLC. Nilai $r$ yang diperoleh adalah 0,9953. Nilai $r$ pada hasil regresi linier menunjukkan linieritas yang baik karena mendekati satu (Watson, 2000).

4. Penetapan kriteria sensitivitas

Kriteria yang digunakan untuk menilai sensitivitas metode pada penelitian ini adalah LOD, LOQ, dan LLOQ. Berdasarkan hasil perhitungan diperoleh nilai LOD sebesar $0,938 \mu \mathrm{g} / \mathrm{mL}$, nilai LOQ sebesar $3,128 \mu \mathrm{g} / \mathrm{mL}$, dan nilai LLOQ sebesar $1,564 \mu \mathrm{g} / \mathrm{mL}$.
5. Penetapan kriteria akurasi dan presisi Tabel 1 menunjukkan nilai dari perolehan kembali, kesalahan sistematik, kesalahan acak, dan HORRAT dari metode penetapan kadar rifampisin dalam darah pada penelitian ini.

Berdasarkan data yang tersaji pada tabel 2, diperoleh informasi bahwa nilai ratarata perolehan kembali dan kesalahan acak dari masing-masing seri kadar masih memenuhi rentang yang diperbolehkan, yaitu untuk perolehan kembali sebesar $100 \pm$ $20 \%$, sedangkan untuk kesalahan acak sebesar kurang dari $15 \%$ untuk metode yang menggunakan HPLC (Anonim, 2009). Nilai HORRAT yang bernilai $0,01,0,005,0,89$ menunjukkan bahwa metode yang digunakan memiliki presisi yang baik, yaitu kurangdari2.

Tabel 2. Nilai perolehan kembali, kesalahan sistematik, kesalahan acak, dan HORRAT pada penetapan kadar rifampisin dalam darah

\begin{tabular}{|c|c|c|c|c|c|c|}
\hline & \multicolumn{2}{|c|}{ Kadar rifampisin } & \multirow[b]{2}{*}{$\begin{array}{c}\text { Recovery } \\
(\%)\end{array}$} & \multirow[b]{2}{*}{$\begin{array}{c}\text { Kesalahan } \\
\text { Sistematik } \\
(\%)\end{array}$} & \multirow[b]{2}{*}{$\begin{array}{c}\text { Kesalahan } \\
\text { Acak (\%) }\end{array}$} & \multirow[b]{2}{*}{ HORRAT } \\
\hline $\begin{array}{l}\text { Diketahui } \\
(\mu \mathrm{g} / \mathrm{mL})\end{array}$ & $\begin{array}{l}\text { Luas } \\
\text { Area }\end{array}$ & $\begin{array}{l}\text { Terukur } \\
(\mu \mathrm{g} / \mathrm{mL})\end{array}$ & & & & \\
\hline \multirow{3}{*}{5} & 79707 & 4,03 & 80,53 & 19,48 & \multirow{4}{*}{0,07} & \multirow{4}{*}{0,01} \\
\hline & 81130 & 4,10 & 81,99 & 18,01 & & \\
\hline & 80919 & 4,09 & 81,77 & 18,23 & & \\
\hline \multirow{2}{*}{$\begin{array}{c}\text { Rata- } \\
\text { rata } \pm S D\end{array}$} & & $4,07 \pm 0,04$ & $81,43 \pm 0,79$ & $18,57 \pm 0,79$ & & \\
\hline & 201400 & 10,29 & 102,87 & $-2,87$ & \multirow{4}{*}{0,03} & \multirow{4}{*}{0,003} \\
\hline \multirow[t]{2}{*}{10} & 200133 & 10,22 & 102,21 & $-2,21$ & & \\
\hline & 200069 & 10,22 & 102,18 & $-2,18$ & & \\
\hline \multirow[t]{2}{*}{$\begin{array}{l}\text { Rata- } \\
\text { rata } \pm S D\end{array}$} & & $10,24 \pm 0,04$ & $102,42 \pm 0,39$ & $-2,42 \pm 0,39$ & & \\
\hline & 259390 & 13,27 & 88,47 & 11,54 & \multirow{4}{*}{4,73} & \multirow{4}{*}{0,44} \\
\hline \multirow[t]{2}{*}{15} & 262664 & 13,44 & 89,59 & 10,41 & & \\
\hline & 242551 & 13,04 & 82,69 & 17,31 & & \\
\hline $\begin{array}{l}\text { Rata- } \\
\text { rata } \pm S D\end{array}$ & & $13,04 \pm 0,56$ & $86,91 \pm 3,70$ & $13,09 \pm 3,70$ & & \\
\hline
\end{tabular}


Tabel 3. Persentase degradasi rifampisin dalam asetonitril (in vivo) pada pemberian rifampisin 50 $\mathrm{mg} / \mathrm{kg}$ BB tikus setelah dilakukan penyimpanan dalam lemari pendingin

\begin{tabular}{cccc}
\hline Jam ke- & Luas area & Kadar rifampisin dalam darah $(\mu \mathrm{g} / \mathrm{mL})$ & Degradasi $(\%)$ \\
\hline 0 & 68872 & 3,468867 & 0 \\
24 & 66997 & 3,372411 & 2,88
\end{tabular}

Berdasarkan nilai parameter kesalahan acak dan recovery, dapat disimpulkan bahwa metode analisis yang digunakan dalam penelitian ini memenuhi kriteria presisi dan akurasi.

6. Penetapan stabilitas rifampisin dalam asetonitril

Parameter untuk menilai stabilitas rifampisin selama proses penyimpanan adalah persentase degradasi. Uji stabilitas rifampisin ini dilakukan selama 24 jam (shortterm temperature stability).

Stabilitas obat dalam spesimen biologis dapat dipengaruhi oleh beberapa faktor, diantaranya adalah sifat kimia obat, matriks, suhu, wadah dan kondisi penyimpanan. Tujuan dari penetapan stabilitas rifampisin dalam asetonitril adalah untuk mengetahui kestabilan rifampisin yang terkandung didalam spesimen biologis selama beberapa waktu jika disimpan dalam lemari pendingin atau freezer dengan suhu $5-10^{\circ} \mathrm{C}$ dikarenakan penginjeksian sampel ke HPLC tidak memungkinkan untuk dibaca secara langsung dan selesai dalam satu hari. Penetapan stabilitas rifampisin dalam spesimen biologis dihitung sebagai persentase degradasi terhadap kadar awal. Pemilihan waktu penetapan stabilitas 24 jam dikarenakan penginjeksian sampel ke HPLC setelah dipreparasi adalah maksimal 24 jam. Jenis stabilitas yang digunakan adalah short term. Setelah penyimpanan 24 jam, kadar rifampisin berkurang, namun persentase degradasi yang terjadi tidak lebih dari $10 \%$ sehingga kadar teofilin yang dianalisis masih stabil

7. Hasil Uji Farmakokinetika

Data penelitian farmakokinetika rifampisin yang diberikan peroral pada kelompok kontrol dan perlakuan masingmasing disajikan pada tabel 4 .

Parameter farmakokinetika diperlukan untuk menginterpretasi perubahanperubahan disposisi obat di dalam tubuh seperti yang terwujud dalam perubahan nilai parameter. Parameter farmakokinetika terdiri dari parameter primer, sekunder, dan turunan. Parameter primer terdiri dari $\mathrm{k}_{\mathrm{a}}, \mathrm{Vd}$, dan $\mathrm{Cl}_{T}$, yang dipengaruhi oleh perubahan salah satu atau lebih variabel fisiologis. Parameter sekunder meliputi $k, t_{1 / 2}$, dan $t_{\text {maks }}$ dimana parameter-parameter tersebut dipengaruhi oleh perubahan parameter primer yang dikarenakan adanya perubahan suatu variabel fisiologis, sedangkan parameter turunan nilainya tidak hanya bergantung pada parameter primer tapi juga dipengaruhi oleh dosis dan kecepatan pemberian obat, contohnya adalah $\mathrm{AUC}_{0-\sim}$, AUMC, $C p_{\text {maks }}$, dan MRT. 
Tabel 4. Data kadar rifampisin dalam darah $(\mu \mathrm{g} / \mathrm{mL})$ pada kelompok kontrol dan perlakuan $(\mathrm{n}=5)$

\begin{tabular}{ccc}
\hline \multirow{2}{*}{$\begin{array}{c}\text { Waktu sampling } \\
\text { (jam ke-) }\end{array}$} & \multicolumn{2}{c}{ Kadar $(\mu \mathrm{g} / \mathrm{mL})$} \\
\cline { 2 - 3 } & $\begin{array}{c}\text { Kelompok Kontrol } \\
\text { (Rata-rata } \pm S E)\end{array}$ & $\begin{array}{c}\text { Kelompok Perlakuan } \\
\text { (Rata-rata } \pm S E)\end{array}$ \\
\hline 0,25 & $0,49 \pm 0,23$ & $0,09 \pm 0,03$ \\
0,5 & $1,22 \pm 0,53$ & $0,17 \pm 0,03$ \\
1 & $1,78 \pm 0,58$ & $0,22 \pm 0,05$ \\
1,5 & $2,43 \pm 1,08$ & $0,24 \pm 0,05$ \\
2 & $1,17 \pm 0,46$ & $0,34 \pm 0,09$ \\
3 & $4,21 \pm 1,06$ & $0,57 \pm 0,12$ \\
4 & $1,35 \pm 0,47$ & $0,29 \pm 0,12$ \\
6 & $1,79 \pm 0,47$ & $0,59 \pm 0,12$ \\
8 & $2,51 \pm 0,65$ & $0,77 \pm 0,24$ \\
10 & $2,27 \pm 0,90$ & $1,08 \pm 0,09$ \\
12 & $1,40 \pm 0,40$ & $0,91 \pm 0,11$ \\
24 & $0,78 \pm 0,27$ & $0,60 \pm 0,11$ \\
\hline
\end{tabular}

Keterangan :

- Kelompok kontrol adalah tikus yang diberikan rifampisin secara peroral dengan dosis $50 \mathrm{mg} / \mathrm{kgBB}$

- Kelompok perlakuan adalah tikus yang diberikan madu peroral dengan dosis 7,65 $\mathrm{mL} / \mathrm{kgBB}$ satu kali sehari selama tujuh hari berturut-turut dan pada hari kedelapan diberikan bersamaan dengan rifampisin dosis $50 \mathrm{mg} / \mathrm{kgBB}$

Tabel 5. Harga parameter farmakokinetika dan uji t tidak berpasangan untuk rifampisin pada kelompok kontrol dan perlakuan

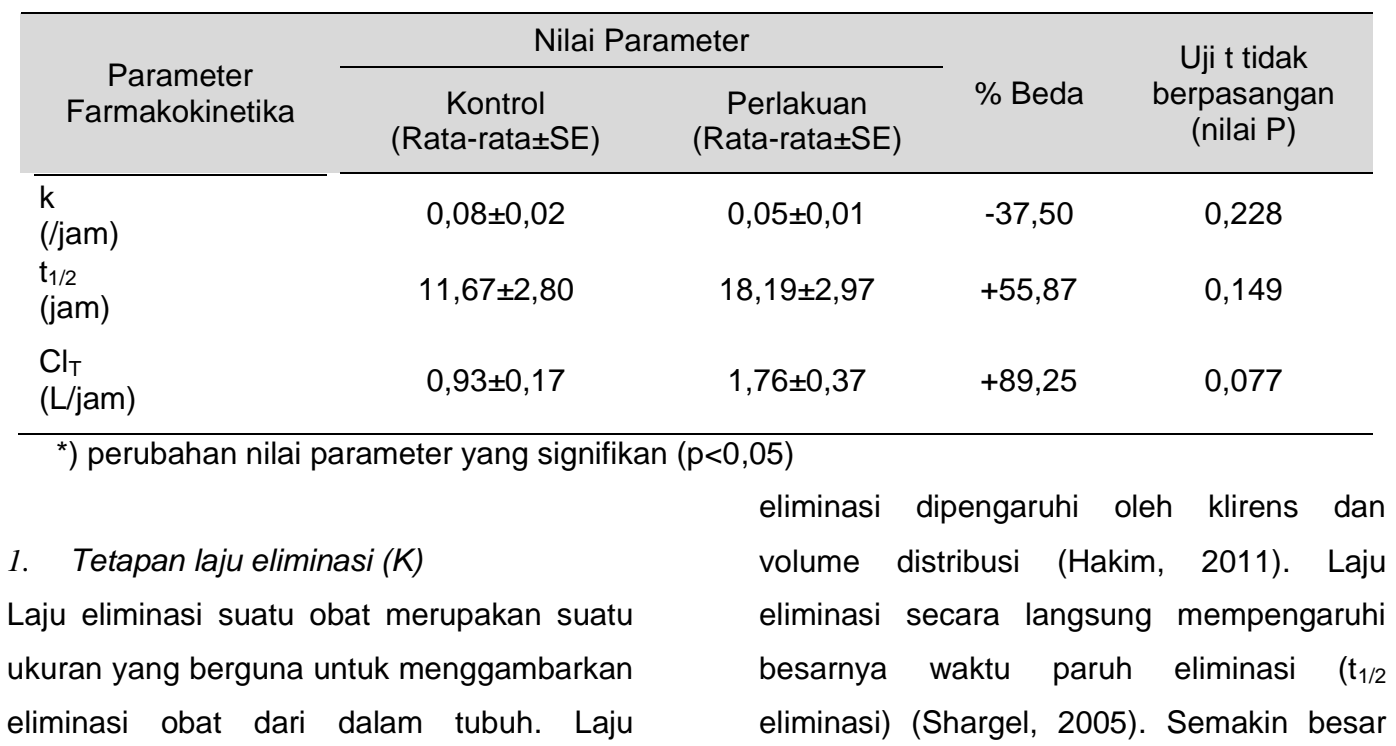


nilai $\mathrm{K}$ maka semakin singkat waktu paruh eliminasi, semakin kecil nilai $\mathrm{K}$ maka semakin lama waktu paruh eliminasi. Semakin besar klirens, maka nilai $\mathrm{K}$ juga makin besar, sehingga eliminasi obat dari dalam tubuh semakin cepat. Nilai $\mathrm{K}$ dapat ditentukan jika nilai klirens diketahui ataupun dapat diketahui secara langsung dari nilai $B$ regresi linier log $\mathrm{Cp}$ (kadar obat dalam plasma) vs $t$ (waktu) pada titik-titik eliminasi obat atau yang dianggap mewakili titik-titik eliminasi suatu obat.

Hasil penelitian ini menunjukkan bahwa praperlakuan madu dosis 7,65 $\mathrm{mL} / \mathrm{kgBB}$ ternyata hanya sedikit menurunkan laju eliminasi rifampisin secara tidak signifikan jika dibandingkan dengan kontrol $(p>0,05)$.

2. Waktu paruh eliminasi ( $\left.t_{1 / 2}\right)$

Waktu paruh eliminasi menunjukkan lamanya waktu yang diperlukan oleh sejumlah obat atau konsentrasi obat untuk dapat tereliminasi menjadi setengahnya (berkurang menjadi setengahnya) (Shargel, 2005). Nilai waktu paruh eliminasi sangat tergantung kepada laju eliminasi obat, klirens total dan volume distribusi (Hakim, 2011). Berdasarkan data penelitian dapat diketahui bahwa pada kelompok perlakuan mengalami peningkatan nilai $t 1 / 2$ walaupun tidak signifikan secara statistik.

3. Klirens total $\left(C l_{t}\right)$

Klirens obat adalah suatu ukuran eliminasi obat dari tubuh tanpa mempermasalahkan mekanisme prosesnya. Eliminasi obat terdiri dari proses metabolisme dan ekskresi. Klirens dapat didefinisikan sebagai volume bersihan suatu obat dari tubuh per satuan waktu $(\mathrm{mL} /$ menit atau L/jam) (Shargel, 2005). Nilai klirens dapat dipengaruhi oleh beberapa faktor fisiologi, seperti fungsi organ dalam mengeliminasi obat dan kecepatan alir darah menuju organ eliminasi obat (Hakim, 2011). Hasil penelitian ini menunjukkan bahwa praperlakuan madu dosis $7,65 \mathrm{~mL} / \mathrm{kgBB}$ ternyata mengakibatkan peningkatan klirens total rifampisin jika dibanding kelompok kontrol, tetapi secara tidak signifikan ( $p>0,05)$.

Hasil penelitian ini tidak menunjukkan peningkatan klirens total secara bermakna yang menunjukkan bahwa metabolisme rifampisin tidak dipercepat akibat pemberian madu. Hal ini dapat terjadi karena beberapa faktor, yang paling mungkin adalah karena prednison tidak mampu mempercepat metabolisme teofilin.

Keterbatasan pada penelitian ini diantaranya adalah nilai $\mathrm{Cp}$ yang diperoleh pada kelompok perlakuan sangat kecil, bahkan berada dibawah nilai LLOQ. Hal ini disebabkan tidak dilakukannya pembuatan kurva baku menggunakan kadar terendah sesuai nilai LLOQ yang diperoleh diawal penelitian, selain itu tidak dilakukan penyesuaian dosis setelah diketahui nilai $\mathrm{Cp}$ yang dihasilkan berada dibawah LLOQ kurva baku, oleh karena itu perlu dilakukan penyesuaian atau optimasi kembali terhadap dosis rifampisin pada tikus. Hal lain yang perlu diperhatikan adalah perlunya dilakukan pembuatan kurva baku pada setiap penetapan kadar rifampisin dalam darah. Berdasarkan hasil penelitian, terlihat bahwa madu dapat menunda absorpsi rifampisin akibatnya nilai $t_{\text {maks }}$ meningkat hingga berada pada jam ke 8-10 waktu sampling, sehingga diperlukan cuplikan yang lebih sering antara jam ke-10 hingga jam ke-24 untuk mengetahui apakah masih terdapat peningkatan $\mathrm{Cp}$ diantara waktu tersebut. 


\section{KESIMPULAN}

Hasil penelitian pengaruh praperlakuan madu dosis 7,65 mL/kgBB tikus terhadap farmakokinetika rifampisin dosis $50 \mathrm{mg} / \mathrm{kgBB}$ tidak berpengaruh secara signifikan terhadap parameter fase eliminasi rifampisin.

\section{DAFTAR PUSTAKA}

Baxter, K. (2008) Stockley's Drug Interaction. Eight Edition. USA: Pharmaceutical Press

Bogdanov S, Jurendic T, Sieber R, Gallmann P.(2008), Honey for Nutrition and Health : A Review. Journal of American College of Nutrition.; 27(6):677-689

Debra C., Quenelle. Jay K., Staas. Gary, A., Winchester et.al.(1999) Efficacy Of Microencapsulated Rifampin In Mycobacterium Tuberculosis-Infected Mice. Antimicrobial Agents And Chemotherapy Journal ; 43(5): 11441151

Dipiro JT, Talbert RL, Yee GC, Matzke GR, Welss BG, Posey LM. (2008) Pharmacotherapy $A$ Pathophysiologic Approach. 7th ed. New York: Mc Graw Hill Medical. Chapter 116, Tuberculosis; p.1845

Goodman, Louis S., Hardman, J. G., Limbird, L. E., eds. Goodman \& Gilman's. (2000), The Pharmacological Basis of Therapeutics, 9th ed. Elmsford. McGraw-Hill, New York: McGraw-Hill.

Hakim L. (2011), Farmakokinetik. Yogyakarta: Bursa IImu

Hemanth Kumar, I. Chandra, R. Geetha, K. Silambu Chelvi. (2004), A validated high-performance liquid chromatography method for the determination of rifampicin and desacetyl rifampicin in plasma and urine. Indian J Pharmacol ; 36(4): 231233

Maulidah, N. (2005) Pengaruh Praperlakuan Madu terhadap Farmakokinetika Sulfametazin pada Tikus [Skripsi]. Yogyakarta: Universitas Islam Indonesia
Neal MJ.(2006), At a Glance Farmakologi Medis [J. Surapsari, trans]. Edisi ke-5. Jakarta: Erlangga

Paramitasari Y. (2012), Pengaruh Pemberian Madu terhadap Profil Farmakokinetik Teofilin pada Tikus Putih Jantan Galur Wistar dengan Metode High Performance Liquid Chromatography (HPLC) [Skripsi]. Yogyakarta: Universitas Islam Indonesia

Shargel, L., Pong, S.W., Yu, A.B.C., 2004, Applied Biopharmaceutics \& Pharmacokinetics, Fifth Edition, McGraw Hill's, New York

Suranto, A.(2004), Khasiat dan Manfaat Madu Herbal. Jakarta: PT. Agromedia Pustaka

Suranto A (2007). Terapi Madu. Jakarta: Penebar Swadaya

Trisnawati, (2005) Pengaruh Pemberian Madu secara Bersamaan dengan Parasetamol terhadap Daya Analgetik Parasetamol pada Mencit Betina Galur Swiss [Skripsi]. Yogyakarta: Universitas Islam Indonesia

Tushar T, Vinod T, Rajan S, Shashindran C, Adithan, C. (2006) Effect of Honey on CYP3A4, CYP2D6, and CYP2C19 Enzyme Activity in Healthy Human Volunteers. Basic \& Clinical Pharmacology; 100:269-272

United Nations Publication; (2009), Guidance for the Validation of Analytical Methodology and Calibration of Equipment used for Testing Illicit Drug in Seizxed Materials and Biological Specimens. New York

Wahyono. D., Hakim. A.R. (2005), Pengaruh Praperlakuan Brokoli (Brassica oleracea L. Var. Botrytis L.) terhadap Farmakokinetika Rifampisin pada Tikus. Majalah Farmasi Indonesia. 16 (3): $177-181$

$\begin{array}{cr}\text { Wahyono D, Hakim } & \text { AR, } \\ \text { Purwatiningsih.(2007), } & \text { Pengaruh } \\ \text { Pemberian Syrup Curcuma Plus } & { }^{\circledR} \\ \text { terhadap Farmakokinetika } & \text { Rifampisin } \\ \text { pada Tikus. Majalah } & \text { Farmasi } \\ \text { Indonesia. 18(4):163-168 } & \end{array}$

Watson DG. (2000) Pharmaceutical Analysis. London: Churchill Livingstone 
28 | Dimas Adhi Pradana

Jurnal IImiah Farmasi Vol. 10 No. 1 Tahun 2013 